\title{
Surface composition-tunable octahedral PtCu nanoalloys advance the electrocatalytic performance on methanol and ethanol oxidation
}

\author{
Fengling Zhao ${ }^{1}$, Qiang Yuan ${ }^{1,2^{*}}$, Bin Luo ${ }^{1}$, Chaozhong Li $^{1}$, Fang Yang ${ }^{1}$, Xiaotong Yang ${ }^{1}$ and \\ Zhiyou Zhou ${ }^{3}$
}

\begin{abstract}
The synthesis of surface composition-tunable Pt-based octahedral nanoalloys is key to unravel the structureproperty relationship in fuel cells. Herein, we report a facile route to prepare composition-tunable $\mathrm{PtCu}$ octahedral nanoalloys by using halogen ions $\left(\mathrm{Br}^{-}\right.$or/and $\left.\mathrm{I}^{-}\right)$as composition modulators. Among these PtCu octahedral nanoalloys, $\mathrm{Pt}_{59} \mathrm{Cu}_{41}$ octahedron exhibits the highest catalytic activity and durability in alkaline solution. The specific activity/mass activity of $\mathrm{Pt}_{59} \mathrm{Cu}_{41}$ octahedron is $20.25 \mathrm{~mA} \mathrm{~cm}^{-2} / 3.24 \mathrm{~A} \mathrm{mg}^{-1} \mathrm{Pt}$, which is 6.64/5.3 times higher than commercial Pt black in $0.5 \mathrm{~mol} \mathrm{~L}^{-1} \mathrm{CH}_{3} \mathrm{OH}$, respectively. In the case of using ethanol $\left(0.5 \mathrm{~mol} \mathrm{~L}^{-1}\right)$ as fuel source, $\mathrm{Pt}_{59} \mathrm{Cu}_{41}$ octahedron shows much better catalytic activity, that is $34.84 \mathrm{~mA} \mathrm{~cm}^{-2} / 5.58 \mathrm{~A} \mathrm{mg}^{-1}$ for specific activity/mass activity, which is $9.16 / 7.34$ times higher than commercial Pt black, respectively. In situ Fourier transform infrared spectroscopy is employed to detect the intermediate species and products for methanol/ethanol oxidation reaction and a plausible mechanism is proposed to explain the improved activity and durability of $\mathrm{Pt}_{59} \mathrm{Cu}_{41}$ octahedron toward methanol/ethanol oxidation in alkaline medium.
\end{abstract}

Keywords: octahedral PtCu alloy, composition and strain-tunable, in situ FTIR, direct methanol/ethanol fuel cells

\section{INTRODUCTION}

Fuel cells have attracted tremendous attention due to their high energy densities and environment-friendly technique. Among them, alcohol fuel cells (AFCs) are widely concerned by different research groups around the world [1-7]. Pt-based nanomaterials are commonly used as electrode catalysts in cathode and anode of fuel cells. However, the commercialization of AFCs suffers from not only the high cost of Pt materials, but also the poisoning of Pt-based electrodes caused by CO-like intermediate. Great efforts have been devoted to addressing these issues and many promising progresses have been achieved. One of the most interesting and efficient strategies is to synthesize Pt-M nanoalloys by using cheap transition metal atoms (such as $\mathrm{Cu}, \mathrm{Co}, \mathrm{Ru}$, and $\mathrm{Pb}$ ). The introduction of those metal atoms into Pt crystal could significantly improve the durability of Pt materials because of the effective ligand effect and/or synergetic effect [8-17]. For example, Wang's group [18] reported that $\mathrm{PtCu}$ nanowires can respectively boost the mass activity of methanol/ethanol oxidation to $1.74 / 2.1 \mathrm{~A} \mathrm{mg}_{\mathrm{Pt}}^{-1}$, together with enhanced durability compared with commercial Pt black in potassium hydroxide $(\mathrm{KOH})$ solution. Xie's group [19] demonstrated enhanced durability and mass activity of $0.515 \mathrm{~A} \mathrm{mg}^{-1}$ Pt on octahedral PtCo alloy compared with commercial $\mathrm{Pt} / \mathrm{C}$ in sulfuric acid medium.

It is well-known that the shape and surface composition of Pt-based nanomaterials are greatly related to their catalytic performances, such as activity and durability [20-29]. Therefore, the shape and composition tunable synthesis of Pt-based nanocrystals is key toward optimizing the electrocatalytic performances of alcohols oxidation. Up to now, a variety of synthetic methods have been developed to achieve this goal, by employing surfactants (e.g, oleylamine, oleic acid, poly(ethyleneoxide)$b$-poly(methyl methacrylate)), small molecules (e.g., amines and carbon monoxide), and halogen anions as

\footnotetext{
${ }^{1}$ Department of Chemistry, College of Chemistry and Chemical Engineering, Guizhou University, Guiyang 550025, China

${ }^{2}$ Key Lab of Organic Optoelectronics \& Molecular Engineering, Tsinghua University, Beijing 100084, China

${ }^{3}$ State Key Laboratory of Physical Chemistry of Solid Surfaces, College of Chemistry and Chemical Engineering, Xiamen University, Xiamen 361005, China

* Corresponding author (email: qyuan@gzu.edu.cn)
} 
structure-directing agents [30-39]. For instance, Dong's group [40] reported the shape-controlled synthesis of PtRu nanoalloys (nanowire, nanorod and nanocube) by changing the surfactants. Sun's group [41] and Wang's group [42] respectively used $\mathrm{KI}$ and $\mathrm{NaI}$ as structuredirecting agent to achieve hierarchical $\mathrm{Pt}-\mathrm{Cu}$ superstructures. However, the chemical composition largely depends on the feeding ratio between Pt precursors and other transition metal precursors [43-46]. Dimitrov et al. [47] recently have reported the synthesis of $\mathrm{Pt}_{x} \mathrm{Cu}_{100-x}$ nanocubes by changing the amount of $\mathrm{Pt} / \mathrm{Cu}$ precursors. Very limited reports have focused on the synthesis of composition tunable Pt-M nanoalloys with the same morphology by changing the structure-directing agents. For example, the $\{111\}$ faceted octahedral Pt nanoparticles show excellent electrocatalytic activity in fuel cells [48-51], which can be attributed to the specific geometry carrying abundant catalytic active sites (e.g, corner, edge and facet). Therefore, the preparation of composition-tunable Pt-based octahedral nanoalloys is a key step, yet challenging, for the applications in fuel cells.

Herein, we report a solvothermal method to synthesize surface composition tunable $\mathrm{PtCu}$ octahedrons by using sodium halides $(\mathrm{NaBr}$ and $\mathrm{NaI})$ as structure-directing agents. The octahedral $\mathrm{PtCu}$ nanoalloys exhibit remarkable electrocatalytic activity and stability toward the electrocatalytic oxidation of methanol/ethanol in alkaline medium. Moreover, in situ Fourier transform infrared spectroscopy (FTIR) was employed to elucidate the intermediates on $\mathrm{PtCu}$ nanoalloys during the electrocatalytic reaction in alkaline medium for the first time. Finally, a plausible mechanism is proposed to explain the improved activity and durability of $\mathrm{PtCu}$ octahedrons toward methanol/ethanol oxidation in alkaline medium.

\section{EXPERIMENTAL SECTION}

\section{Materials}

$\mathrm{NaI}$ (A.R.), $\mathrm{NaBr}$ (A.R.), $\mathrm{C}_{2} \mathrm{H}_{5} \mathrm{OH}$ (99.9\%), $\mathrm{CH}_{3} \mathrm{OH}$ (99.5\%), $\mathrm{KOH}$ (A.R.) and N,N-dimethylformamide (DMF, 99.8\%) were obtained from Aladdin. Pd black, $\mathrm{Pt}$ black, copper(II) acetylacetonate $\left(\mathrm{Cu}(\mathrm{acac})_{2}, 97 \%\right)$ and platinum(II) acetylacetonate $\left(\mathrm{Pt}(\mathrm{acac})_{2}, 97 \%\right)$ were pursued from Sigma-Aldrich. All the chemicals were used as received without further purification.

\section{Synthesis of PtCu octahedral nanocrystals}

For $\mathrm{Pt}_{59} \mathrm{Cu}_{41}$ nanoalloys, $33 \mathrm{mg} \mathrm{NaI}, 46 \mathrm{mg} \mathrm{NaBr}$ (molar ratio of $\left.\mathrm{I}^{-} / \mathrm{Br}^{-}=1: 2\right)$ were dissolved in $8 \mathrm{~mL} \mathrm{~N}, N$-dimethylformamide containing $0.03 \mathrm{mmol} \mathrm{Pt}(\mathrm{acac})_{2}$,
$0.06 \mathrm{mmol} \mathrm{Cu}(\mathrm{acac})_{2}$ and $30 \mathrm{mg}$ polyvinyl pyrrolidone, and then the solution was placed in a Teflon-lined stainless-steel autoclave and kept at $150^{\circ} \mathrm{C}$ for $8 \mathrm{~h}$. The dark products were washed with ethanol through centrifugation at $10,000 \mathrm{rpm}$ for $10 \mathrm{~min}$ for several times. Finally, the product was kept in ethanol. The $\mathrm{Pt}_{63} \mathrm{Cu}_{37}$ (49.5 mg NaI, $35 \mathrm{mg} \mathrm{NaBr}$ (molar ratio of $\mathrm{I}^{-} / \mathrm{Br}^{-}=1: 1$ )), $\mathrm{Pt}_{49} \mathrm{Cu}_{51}$ (68.5 mg NaBr) and $\mathrm{Pt}_{45} \mathrm{Cu}_{55}$ (99.2 mg NaI) alloyed octahedrons were synthesized using the same process as that of $\mathrm{Pt}_{59} \mathrm{Cu}_{41}$ nanoalloys except for the deference of sodium halide. Contents of $\mathrm{Pt}$ and $\mathrm{Cu}$ in $\mathrm{PtCu}$ nanooctahedra were obtained via inductively coupled plasma optical emission spectrometer (ICP-OES) (Table S1).

\section{Measurements of electrocatalytic performance}

Electrocatalytic tests were performed by a conventional three-electrode cell equipped with salt bridge using a $\mathrm{CHI}$ 760E electrochemical analyzer (CHI Instruments, Shanghai, Chenghua Co., Ltd.) at room temperature. The ultrapure water $(18.25 \mathrm{M} \Omega \mathrm{cm})$ was used as solvent and purified through a Milli-Q Lab system (Nihon Millipore Ltd.). The glassy carbon (GC, $\Phi=5 \mathrm{~mm}$ ) was used as the working electrode. Before the electrochemical test, the alumina powder with size of $0.05 \mu \mathrm{m}$ was used to polish the GC electrode. The suspension of $\mathrm{PtCu}$ nanocrystals was spread on the polished GC electrode, and before the electrode was nearly dried, $1.5 \mu \mathrm{L}$ of $1.0 \mathrm{wt} . \%$ Nafion solution was spread on the electrode surface. A platinum foil and $\mathrm{Ag} / \mathrm{AgCl}$ electrode were utilized as the counter and reference electrode, respectively. The cyclic voltammograms (CVs) were recorded in $\mathrm{N}_{2}$-saturated $0.1 \mathrm{~mol} \mathrm{~L}^{-1} \mathrm{KOH}$ solution or $0.5 \mathrm{~mol} \mathrm{~L}^{-1} \mathrm{KOH}+$ $0.5 \mathrm{~mol} \mathrm{~L}^{-1}$ methanol/ethanol solution, scanned from -0.8 to $0.2 \mathrm{~V}$ at a rate of $50 \mathrm{mV} \mathrm{s}^{-1}$.

\section{RESULTS AND DISCUSSION}

\section{Structure characterizations}

Fig. 1a-e are the transmission electron microscopy (TEM) images and composition diagram of octahedral $\mathrm{Pt}_{63} \mathrm{Cu}_{37}, \mathrm{Pt}_{59} \mathrm{Cu}_{41}, \mathrm{Pt}_{49} \mathrm{Cu}_{51}$ and $\mathrm{Pt}_{45} \mathrm{Cu}_{55}$ nanoalloys synthesized by tuning the amount of $\mathrm{NaI}$ and/or $\mathrm{NaBr}$ while keeping other synthetic conditions the same. From Fig. la-d, we can see these PtCu nanocrystals are octahedral. The size of these $\mathrm{PtCu}$ nanocrystals is uniform, around $14 \mathrm{~nm}$. The crystal phase of these PtCu octahedrons was determined by X-ray powder diffraction (XRD). Fig. If displays that there are four typical face-centered cubic (fcc) structure peaks which belongs to (111), (200), (220) 

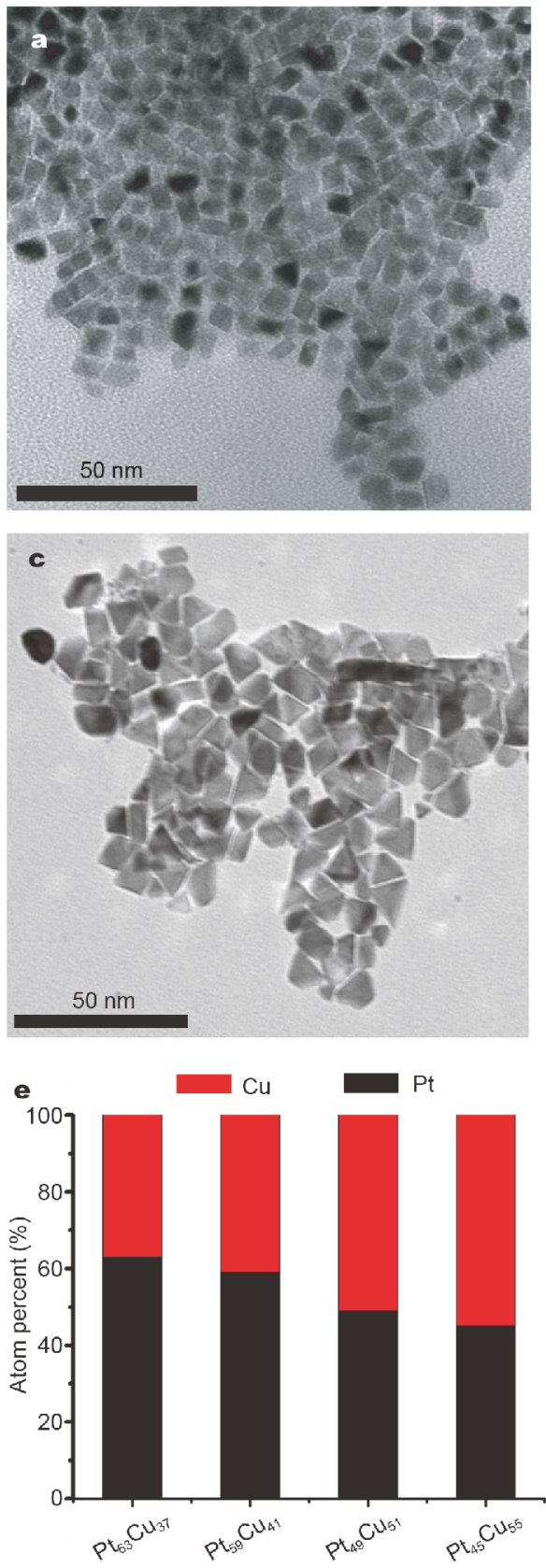
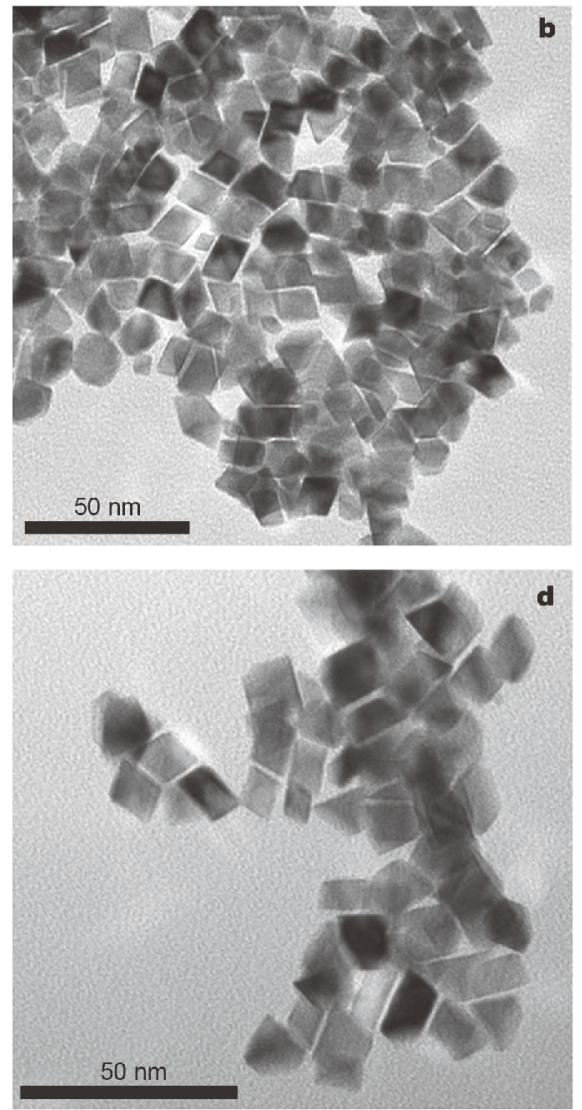

$\mathbf{f}$
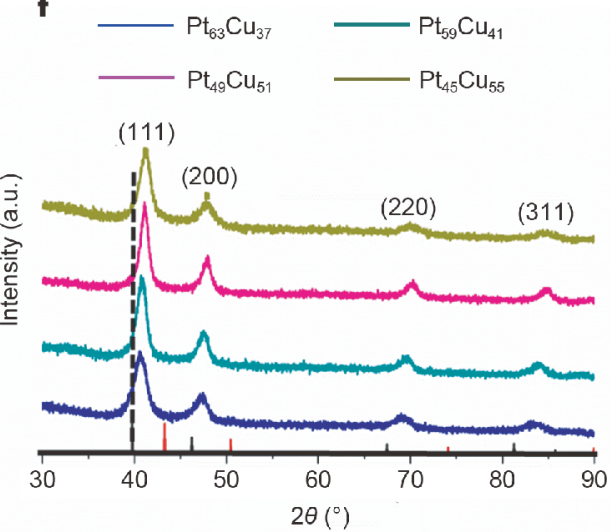

Figure 1 TEM images of (a) $\mathrm{Pt}_{63} \mathrm{Cu}_{37}$, (b) $\mathrm{Pt}_{59} \mathrm{Cu}_{41}$, (c) $\mathrm{Pt}_{49} \mathrm{Cu}_{51}$ and (d) $\mathrm{Pt}_{45} \mathrm{Cu}_{55}$. (e) Composition information on $\mathrm{Pt}$ and Cu for $\mathrm{PtCu}$ nanoalloys. (f) $\mathrm{XRD}$ patterns of the $\mathrm{PtCu}$ nanoalloys with different compositions.

and (311) crystal facets (JCPDS-04-0836 and JCPDS-652868). And these peaks shift to higher angles as the $\mathrm{Cu}$ content increases, which is caused by the incorporation of smaller $\mathrm{Cu}$ atoms into the lattice of Pt to form alloy structure and in accordance with Vegard's law [41-42,4445]. It leads to the lattice contraction of PtCu nanoalloys associated with surface strain, which will enhance the catalytic performances of metal nanocrystals (Table 1)
[52-55]. The lattice fringes of $\mathrm{Pt}_{59} \mathrm{Cu}_{41}$ nanocrystals are clearly shown in Fig. 2a, b, with a lattice spacing of $0.216 \mathrm{~nm}$, showing that the nanocrystals are bounded by $\{111\}$ facets. The scanning TEM (STEM) image in Fig. 3a also indicates the PtCu nanocrystals are octahedral. Elemental mapping analysis (Fig. 3b-d) shows the $\mathrm{Pt}$ and $\mathrm{Cu}$ atoms have a uniform distribution in the nanocrystals, which also implies that the octahedral PtCu nanocrystals 
Table 1 XRD results of standard Pt crystal and as-prepared PtCu octahedral crystals

\begin{tabular}{cccc}
\hline Crystal & $2 \theta\left(^{\circ}\right)(111)$ & Lattice parameter $\left(\AA^{-1}\right)$ & Strain $(\%)$ \\
\hline Pt-crystal & 39.754 & 0.2205 & $/$ \\
$\mathrm{Pt}_{63} \mathrm{Cu}_{37}$ & 40.471 & 0.2243 & 1.7 \\
$\mathrm{Pt}_{59} \mathrm{Cu}_{41}$ & 40.666 & 0.2253 & 2.2 \\
$\mathrm{Pt}_{49} \mathrm{Cu}_{51}$ & 41.084 & 0.2275 & 3.2 \\
$\mathrm{Pt}_{45} \mathrm{Cu}_{55}$ & 41.101 & 0.2277 & 3.3 \\
\hline
\end{tabular}

have alloy structure.

As a sensitive technology for measuring the surface of materials, X-Ray photoelectron spectroscopy (XPS) is widely utilized to analyze the electronic structure and surface composition of substances within $2.0 \mathrm{~nm}$. The two peaks centered at 71.5 and $74.8 \mathrm{eV}$ for the $\mathrm{Pt}_{59} \mathrm{Cu}_{41}$ sample can be identified for the $\mathrm{Pt} 4 \mathrm{f}_{7 / 2}$ and $\mathrm{Pt} 4 \mathrm{f}_{5 / 2}$ (Fig. 4a). The binding energy for $\mathrm{Pt} 4 \mathrm{f}$ in the $\mathrm{Pt}_{59} \mathrm{Cu}_{41}$ sample has a positive shift, around $0.3 \mathrm{eV}$, compared with

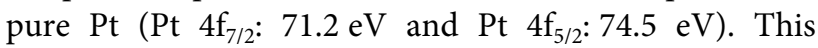
implies that the d-band center of Pt has a downshift due to the introduced $\mathrm{Cu}$ atoms [11]. The binding energies of $\mathrm{Cu} 2 \mathrm{p}_{3 / 2}$ and $\mathrm{Cu} 2 \mathrm{p}_{1 / 2}$ are located at 932.1 and $952.1 \mathrm{eV}$ for the $\mathrm{Pt}_{59} \mathrm{Cu}_{41}$ sample (Fig. $4 \mathrm{~b}$ ), which negatively shift to a lower value compared with pure $\mathrm{Cu}\left(\mathrm{Cu} 2 \mathrm{p}_{3 / 2}: 932.5 \mathrm{eV}\right.$, and $\mathrm{Cu} 2 \mathrm{p}_{1 / 2}: 952.5 \mathrm{eV}$ ). The analysis results of XPS demonstrate that $\mathrm{Pt}$ and $\mathrm{Cu}$ atoms coexist in nano surface and these exotic atoms have a strong electron interaction, which will build the synergistic active sites and improve the activity and durability of electrocatalysts $[11,53,56]$.

\section{Electrochemical measurements}

The electrocatalytic performances of $\mathrm{PtCu}$ nanoalloys were investigated in alkaline solution with commercial $\mathrm{Pt}$ black as a contrast. The PtCu octahedral nanoalloys displayed a composition-dependent electrocatalytic perfor- mance (Fig. S1 and Fig. 5).

The specific activity (SA) that stands for intrinsic electrocatalytic capacity of an electrocatalyst is generally accepted to compare the electrocatalytic activities of catalysts with different surface compositions. For methanol oxidation, the SA of commercial Pd black, commercial Pt black, $\mathrm{Pt}_{63} \mathrm{Cu}_{37}, \mathrm{Pt}_{59} \mathrm{Cu}_{41}, \mathrm{Pt}_{49} \mathrm{Cu}_{51}$ and $\mathrm{Pt}_{45} \mathrm{Cu}_{55}$ nanoalloys is $3.21,3.05,17.05,20.25,9.4$ and $8.59 \mathrm{~mA} \mathrm{~cm}^{-2}$, respectively (Fig. $5 \mathrm{a}, \mathrm{b}$ and Fig. S3b). The $\mathrm{Pt}_{59} \mathrm{Cu}_{41}$ nanoalloys exhibit the best SA, 6.31/6.64 times higher than commercial Pd/Pt black. Similarly, $\mathrm{Pt}_{59} \mathrm{Cu}_{41}$ nanoalloys exhibit the best mass activity (MA) among these samples (Figs S2a and S3c). The MA of $\mathrm{Pt}_{59} \mathrm{Cu}_{41}$ nanoalloys is $3.24 \mathrm{~A} \mathrm{mg}^{-1} \mathrm{Pt}, 5.7 / 5.3$ times higher than that of commercial Pd black $\left(0.57 \mathrm{~A} \mathrm{mg}^{-1} \mathrm{Pd}\right) / \mathrm{Pt}$ black $\left(0.61 \mathrm{~A} \mathrm{mg}^{-1} \mathrm{Pt}_{\mathrm{t}}\right)$. For ethanol oxidation (Fig. $5 c$, d, Figs S2b and S3e, f), the SA/MA of $\mathrm{Pt}_{63} \mathrm{Cu}_{37}, \mathrm{Pt}_{59} \mathrm{Cu}_{41}, \mathrm{Pt}_{49} \mathrm{Cu}_{51}, \mathrm{Pt}_{45} \mathrm{Cu}_{55}$ nanoalloys, commercial Pd black and commercial Pt black is $33.49 / 5.25,34.84 / 5.58,20.3 / 3.14,17.42 / 2.67,5.53 / 0.99$ and $3.80 / 0.76 \mathrm{~mA} \mathrm{~cm}^{-2} / \mathrm{A} \mathrm{mg}^{-1} \mathrm{Pt}$, respectively. Among them, the $\mathrm{Pt}_{59} \mathrm{Cu}_{41}$ nanoalloys display the best SA/MA, 6.30/5.63 and 9.16/7.34 times higher than commercial Pd black and Pt black, respectively. Meanwhile, the onset potential of methanol/ethanol oxidation (Fig. 5a, c, inset) shows that the reaction dynamics of $\mathrm{Pt}_{59} \mathrm{Cu}_{41}$ octahedrons is much faster than that of commercial Pt black, which results in much better catalytic activity of $\mathrm{Pt}_{59} \mathrm{Cu}_{41}$ octahedral nanoalloys than that of commercial Pt black. The current-time $(i-t)$ tests show that the durability of $\mathrm{PtCu}$ nanoalloys is better than that of $\mathrm{Pt} / \mathrm{Pd}$ black for both methanol and ethanol electrooxidation (Fig. 5e, $\mathrm{f}$ and Fig. S3d, S3g). It is worth noting that the durability of $\mathrm{PtCu}$ nanoalloys for methanol oxidation is obviously better than that for ethanol oxidation. After $3600 \mathrm{~s}$, for methanol/ethanol oxidation, the remaining current density of $\mathrm{Pt}_{49} \mathrm{Cu}_{51}, \mathrm{Pt}_{45} \mathrm{Cu}_{55}, \mathrm{Pt}_{63} \mathrm{Cu}_{37}$ and $\mathrm{Pt}_{59} \mathrm{Cu}_{41}$
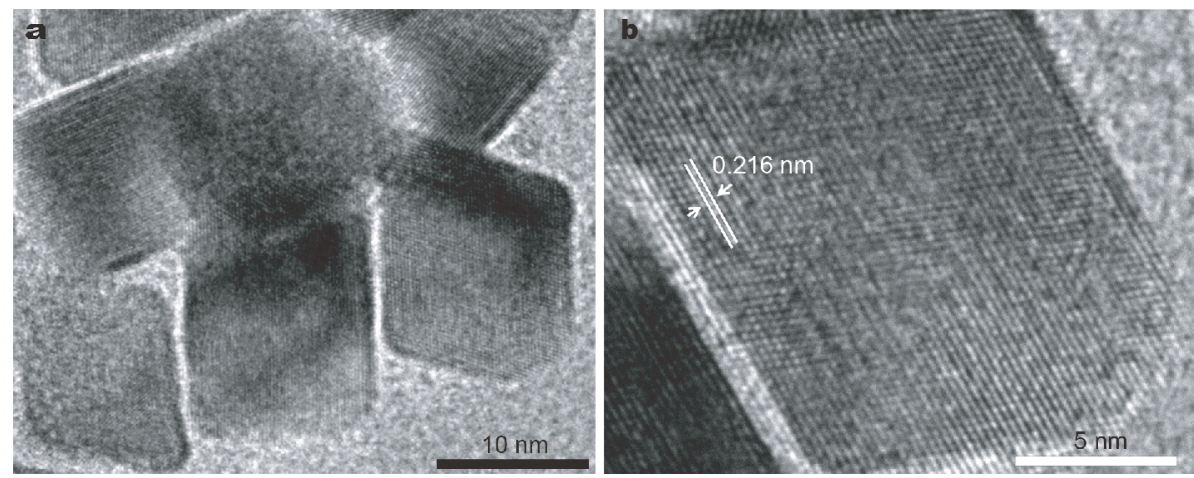

Figure 2 High resolution TEM (HRTEM) images of $\mathrm{Pt}_{59} \mathrm{Cu}_{41}$ nanoalloys with different magnifications. 

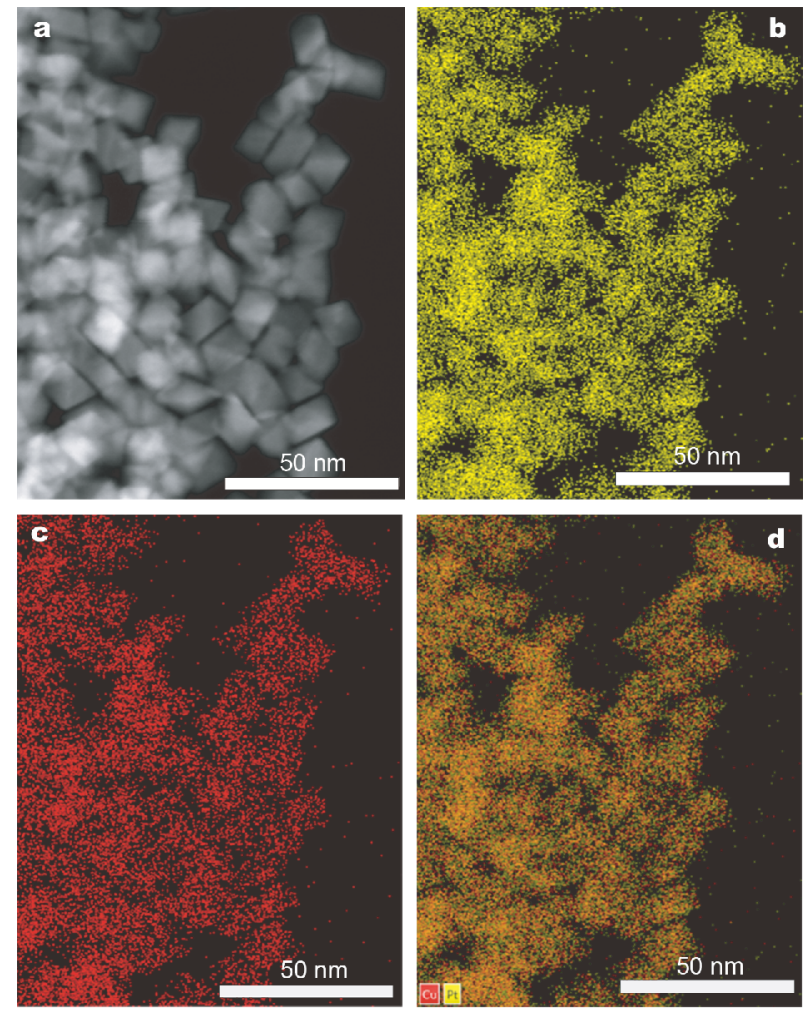

Figure 3 (a) High angle annular dark field-STEM (HAADF-STEM) image, (b) elemental maps of $\mathrm{Pt}$ (yellow), (c) $\mathrm{Cu}$ (red), and (d) overlap (Pt and $\mathrm{Cu}$ ) of $\mathrm{Pt}_{59} \mathrm{Cu}_{41}$ nanoalloys.

nanoalloys are $1.95,1.86,2.15$ and $2.44 \mathrm{~mA} \mathrm{~cm}^{-2}$, while that of $\mathrm{Pd} / \mathrm{Pt}$ black is $0.033 / 0.46 \mathrm{~mA} \mathrm{~cm}^{-2}$. And the $\mathrm{Pt}_{59} \mathrm{Cu}_{41}$ nanoalloys display the best durability. We further utilized accelerated durability tests (ADT) to confirm the stability of $\mathrm{Pt}_{59} \mathrm{Cu}_{41}$ nanoalloys and Pt black in $0.1 \mathrm{~mol} \mathrm{~L}^{-1} \mathrm{KOH}$ condition between -0.5 and $0 \mathrm{~V}$ at $100 \mathrm{mV} \mathrm{s}^{-1}$. After 2000 cycles (Fig. 6a, b), the electrochemically active surface areas (ECSA) of $\mathrm{Pt}_{59} \mathrm{Cu}_{41}$ nanoalloys and Pt black only decrease by $1.2 \%$ and
$17.25 \%$, respectively, relative to initial ECSA, which also indicates the $\mathrm{Pt}_{59} \mathrm{Cu}_{41}$ nanoalloys have a better durability than commercial Pt black. The regeneration capacity of catalyst has also been generally used to evaluate the performance of catalyst. As shown in Fig. $6 \mathrm{c}-\mathrm{f}$, for both methanol and ethanol oxidation, the $\mathrm{SA}$ of $\mathrm{Pt}_{59} \mathrm{Cu}_{41}$ nanoalloys has a very small decrease, below $4 \%$, while the SA of Pt black has an obvious decrease, beyond 15\% (for methanol) and 33\% (for ethanol). These results exhibit that the $\mathrm{Pt}_{59} \mathrm{Cu}_{41}$ nanoalloys have better regeneration capacity than commercial Pt black. Furthermore, the MA of $\mathrm{Pt}_{59} \mathrm{Cu}_{41}$ nanoalloys increases to $5.12 / 7.30 \mathrm{~A} \mathrm{mg}^{-1} \mathrm{Pt}$ when tested in $1.0 \mathrm{~mol} \mathrm{~L}^{-1}$ methanol/ethanol solution (Fig. S4). It is worth pointing out that these values are competitive compared with previous reports (Tables S2 and S3) $[43,44,57-63]$.

\section{In situ FTIR spectra of methanol/ethanol oxidation}

In order to clarify the reasons why the octahedral $\mathrm{Pt}_{59} \mathrm{Cu}_{41}$ alloys have better durability than Pt black and why the durability of octahedral $\mathrm{Pt}_{59} \mathrm{Cu}_{41}$ nanoalloys in methanol oxidation is much better than that in ethanol oxidation, we performed in situ FTIR characterizations of octahedral $\mathrm{Pt}_{59} \mathrm{Cu}_{41}$ alloys and $\mathrm{Pt}$ black in $0.5 \mathrm{~mol} \mathrm{~L}^{-1} \mathrm{KOH}+$ $0.5 \mathrm{~mol} \mathrm{~L}^{-1} \mathrm{CH}_{3} \mathrm{OH}$ or $\mathrm{CH}_{3} \mathrm{CH}_{2} \mathrm{OH}$ solution. The test potential ranges from -0.8 to $0.2 \mathrm{~V}$ with a $0.1 \mathrm{~V}$ interval. For methanol oxidation, as shown in Fig. 7a, b and Table 2, no carbon monoxide peak is observed, which agrees with previous reports, namely, alcohol oxidation in an alkaline solution has almost no carbon monoxide poisoning intermediate (generally observed at around $2050 \mathrm{~cm}^{-1}$ ) [64]. The peaks around 1380 and $1590 \mathrm{~cm}^{-1}$ are attributed to formate [65]. Two peaks around $1380 \mathrm{~cm}^{-1}$ are observed on Pt black from -0.5 to $-0.3 \mathrm{~V}$, which are the typical peaks of formate (Fig. 7a); however, this phenomenon is not observed on octahedral $\mathrm{Pt}_{59} \mathrm{Cu}_{41}$ nanoalloys (Fig. $7 \mathrm{~b}$ ), and a strong peak of carbonate ap-
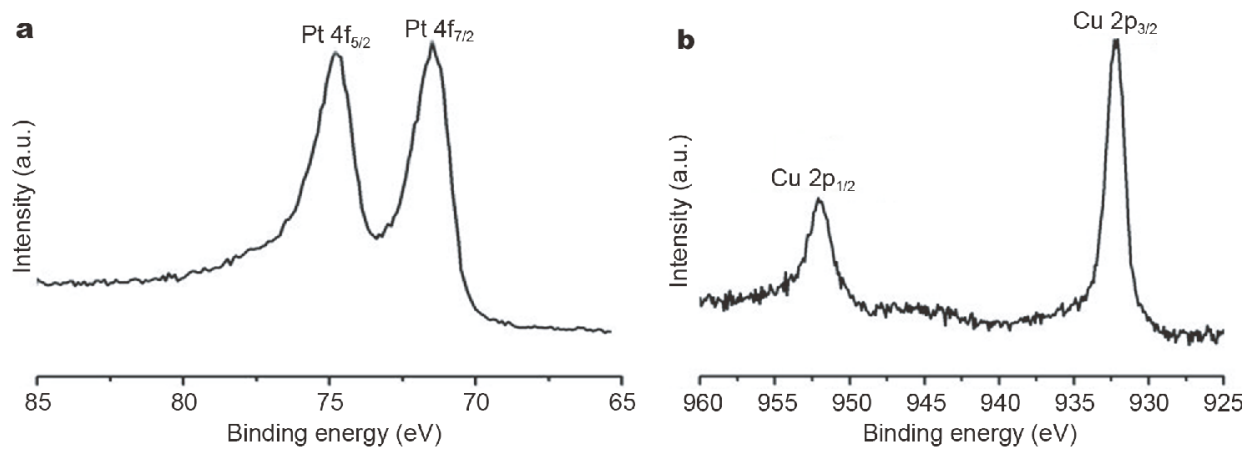

Figure 4 XPS spectra of $\mathrm{Pt} 4 \mathrm{f}(\mathrm{a})$ and $\mathrm{Cu} 2 \mathrm{p}$ (b) of $\mathrm{Pt}_{59} \mathrm{Cu}_{41}$ nanoalloys. 

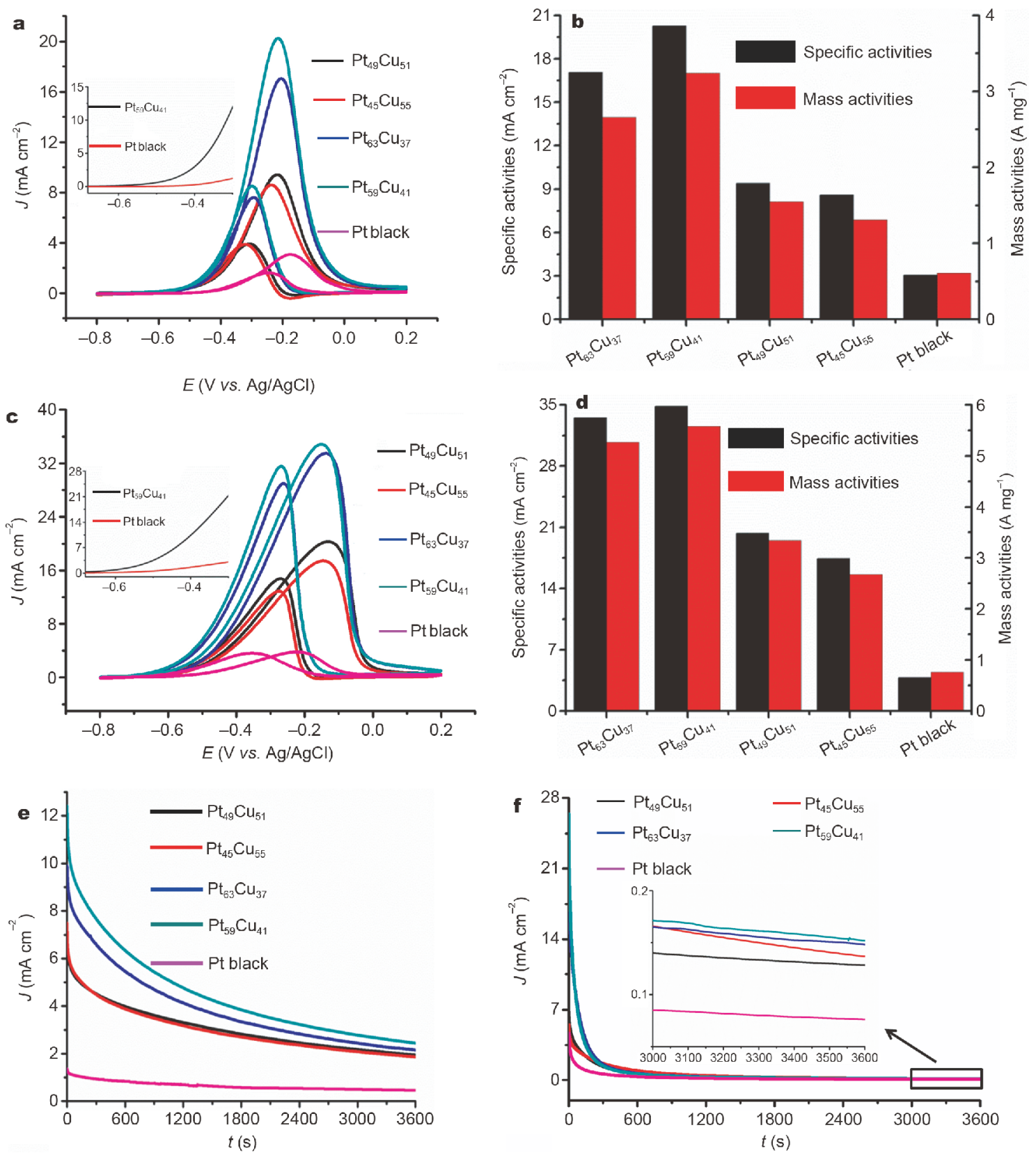

Figure 5 (a) CV curves of specific activity, (b) columns of specific activity and mass activity, (e) $i$ - $t$ curves (tested at $-0.3 \mathrm{~V}$ for $3600 \mathrm{~s}$ ) for catalysts in $0.5 \mathrm{~mol} \mathrm{~L}{ }^{-1} \mathrm{KOH}+0.5 \mathrm{~mol} \mathrm{~L}^{-1} \mathrm{CH}_{3} \mathrm{OH}$. (c) Specific activity curves, (d) columns of specific activity and mass activity, (f) $i$ - $t$ curves (tested at $-0.3 \mathrm{~V}$ for $3600 \mathrm{~s}$ ) for catalysts in $0.5 \mathrm{~mol} \mathrm{~L}^{-1} \mathrm{KOH}+0.5 \mathrm{~mol} \mathrm{~L}^{-1} \mathrm{C}_{2} \mathrm{H}_{5} \mathrm{OH}$ (insets in a and $\mathrm{c}$ are linear scanning curves of $\mathrm{Pt}_{59} \mathrm{Cu}_{41}$ and $\mathrm{Pt}_{\mathrm{t}}$ black).

pears at $-0.6 \mathrm{~V}$, which implies that carbonate is directly formed on octahedral $\mathrm{Pt}_{59} \mathrm{Cu}_{41}$ nanoalloys. Peaks around $2340 \mathrm{~cm}^{-1}$ belong to carbon dioxide [66], and Pt black has a stronger carbon dioxide peak than octahedral $\mathrm{Pt}_{59} \mathrm{Cu}_{41}$ nanoalloys, which indicates carbon dioxides are strongly adsorbed on Pt black and occupy the catalytic active sites, leading to less activity and durability than octahedral
$\mathrm{Pt}_{59} \mathrm{Cu}_{41}$ nanoalloys. Another interesting phenomenon is, with the increase of potential, the peaks of carbon dioxide are much stronger on Pt black than that on octahedral $\mathrm{Pt}_{59} \mathrm{Cu}_{41}$ nanoalloys. However, the peaks of carbonate on Pt black are much weaker than that on octahedral $\mathrm{Pt}_{59} \mathrm{Cu}_{41}$ nanoalloys. These phenomena imply that the carbon dioxide adsorbs more strongly on the surface of $\mathrm{Pt}$ 

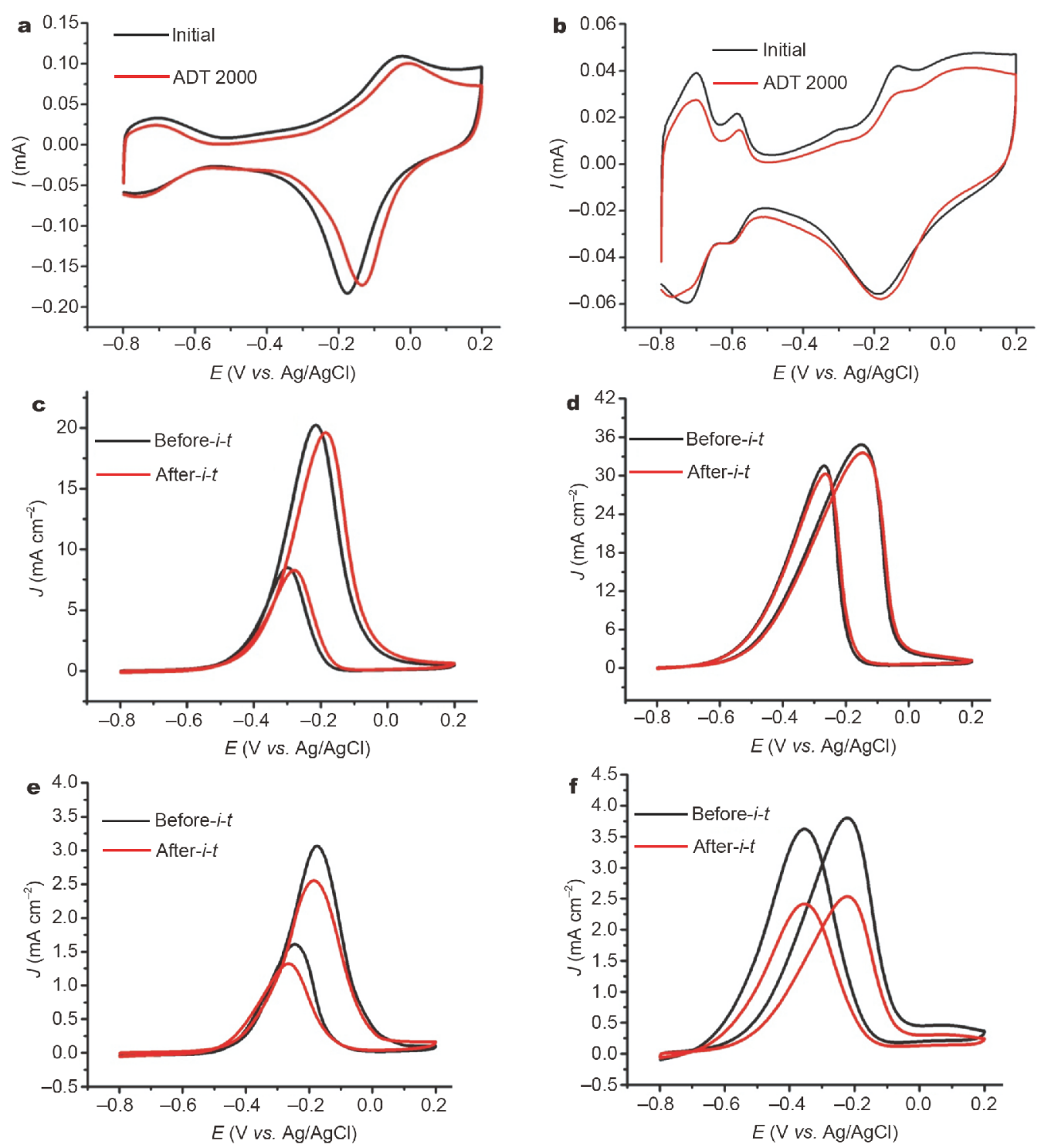

Figure $6 \mathrm{CVs}$ of $\mathrm{Pt}_{59} \mathrm{Cu}_{41}$ nanoalloys (a) and commercial Pt black (b) before and after ADTs at a rate of $100 \mathrm{mV} \mathrm{s}^{-1}$. CVs of $\mathrm{Pt}_{59} \mathrm{Cu}_{41}$ nanoalloys in $0.5 \mathrm{~mol} \mathrm{~L}^{-1} \mathrm{KOH}+0.5 \mathrm{~mol} \mathrm{~L}^{-1} \mathrm{CH}_{3} \mathrm{OH}(\mathrm{c}) / \mathrm{C}_{2} \mathrm{H}_{5} \mathrm{OH}$ (d) before and after $i-t$ test. CVs of Pt black in $0.5 \mathrm{~mol} \mathrm{~L}^{-1} \mathrm{KOH}^{-1} 0.5 \mathrm{~mol} \mathrm{~L}^{-1} \mathrm{CH}_{3} \mathrm{OH}(\mathrm{e}) /$ $\mathrm{C}_{2} \mathrm{H}_{5} \mathrm{OH}(\mathrm{f})$ before and after $i-t$ test.

black and is harder to convert to carbonate. While the carbon dioxide adsorbs weakly on the surface of octahedral $\mathrm{Pt}_{59} \mathrm{Cu}_{41}$ nanoalloys and is more easily converted to carbonate, thus releasing the catalytic active sites and having higher energy conversion efficiency. On the other hand, water consumption bands are in the range of 25003000 and $1700-2000 \mathrm{~cm}^{-1}$ (Fig. $7 \mathrm{a}, \mathrm{b}$ ), the intensities of water consumption bands on octahedral $\mathrm{Pt}_{59} \mathrm{Cu}_{41}$ nanoalloys are obviously higher than Pt black, indicating the better ability of $\mathrm{Pt}_{59} \mathrm{Cu}_{41}$ nanoalloys in activating water than Pt black, producing more reactive oxygen species and resulting in much higher catalytic activity.

As for ethanol electrooxidation (Fig. 7c, d and Table 2), the symmetric and antisymmetric stretching vibrations of acetate anion appeared at around 1420 and $1550 \mathrm{~cm}^{-1}$, respectively. The intensities of the two peaks are almost the same, generally accepted as the standard peak of acetate [67]. At $-0.7 \mathrm{~V}$, We can observe the two peaks of acetic acid and water consumption bands on octahedral $\mathrm{Pt}_{59} \mathrm{Cu}_{41}$ nanoalloys, but not on Pt black, indicating that the octahedral $\mathrm{Pt}_{59} \mathrm{Cu}_{41}$ nanoalloys can activate water and ethanol more easily, leading to better 

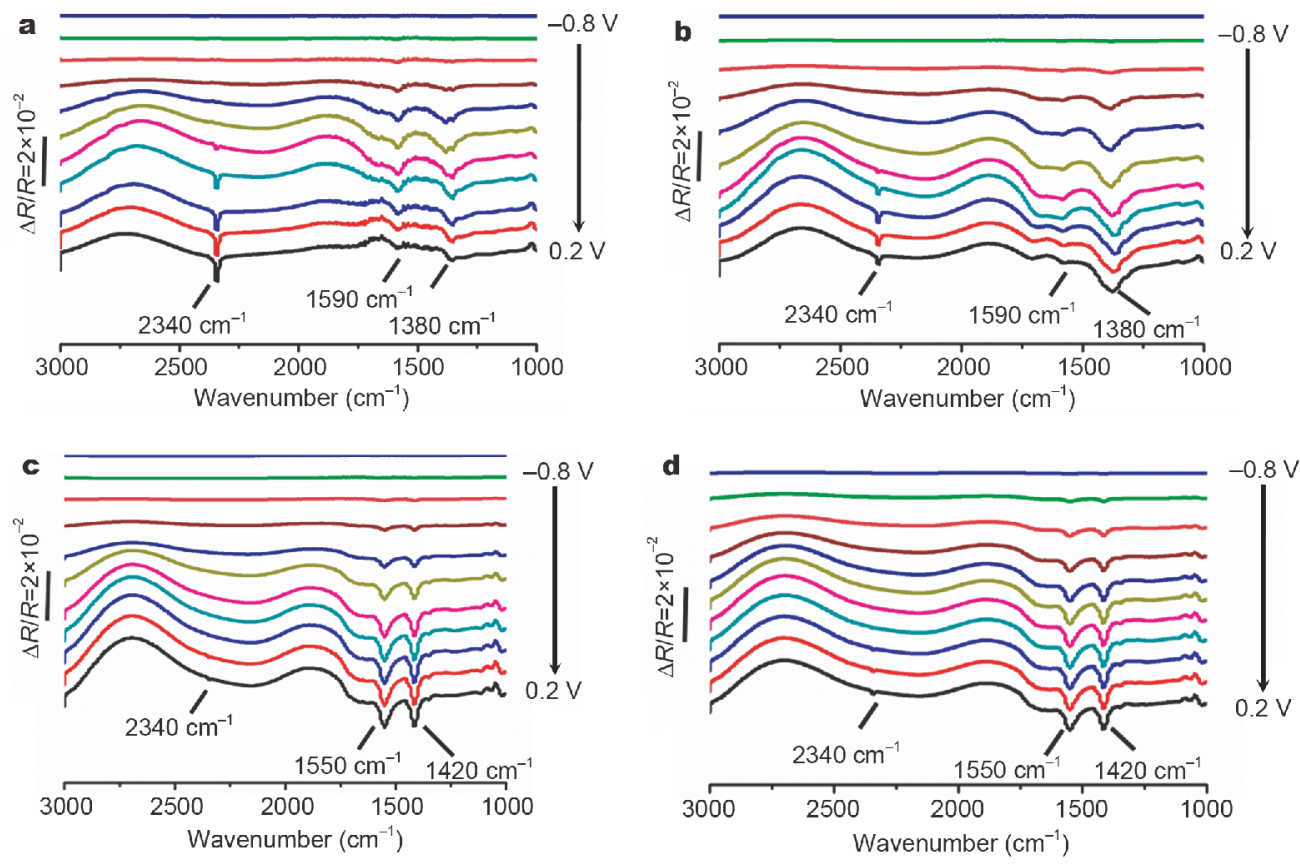

Figure 7 In situ FTIR spectra of commercial Pt black (a) and $\mathrm{Pt}_{59} \mathrm{Cu}_{41}$ nanoalloy (b) in $0.5 \mathrm{~mol} \mathrm{~L}^{-1} \mathrm{KOH}+0.5 \mathrm{~mol} \mathrm{~L}^{-1} \mathrm{CH}_{3} \mathrm{OH}$. In situ FTIR spectra of Pt black (c) and $\mathrm{Pt}_{59} \mathrm{Cu}_{41}$ nanoalloy (d) in $0.5 \mathrm{~mol} \mathrm{~L}^{-1} \mathrm{KOH}+0.5 \mathrm{~mol} \mathrm{~L}^{-1} \mathrm{C}_{2} \mathrm{H}_{5} \mathrm{OH}$ (the range of test is between -0.8 and $0.2 \mathrm{~V}$, and each step is $0.1 \mathrm{~V})$.

Table 2 Assignments of the in situ FTIR spectrum of methanol/ethanol oxidation reaction

\begin{tabular}{cc}
\hline Wavenumbers $\left(\mathrm{cm}^{-1}\right)$ & Peak assignment \\
\hline 2340 & $\mathrm{CO}_{2}$ symmetric stretching vibration \\
& $\begin{array}{c}\text { Symmetric and asymmetric C-O bonds } \\
\text { stretching vibration of acetate ions } \\
\text { Symmetric and asymmetric C-O bonds } \\
\text { stretching vibration of formate }\end{array}$ \\
1380 and 1550 & O-H stretching absorption \\
$2500-3000$ & O-H stretching absorption \\
$1700-2000$ & $\mathrm{CO}_{3}{ }^{2-}$ \\
1380 &
\end{tabular}

catalytic activity. In addition, the peaks of acetic acid on octahedral $\mathrm{Pt}_{59} \mathrm{Cu}_{41}$ nanoalloys are weaker than Pt black form 0 to $0.2 \mathrm{~V}$, because acetate species are CO-like intermediates in ethanol oxidation that would poison the electrocatalyst, and result in the durability decrease. At the beginning from $0 \mathrm{~V}$, the peaks of carbon dioxide are detected on octahedral $\mathrm{Pt}_{59} \mathrm{Cu}_{41}$ nanoalloys, but cannot be observed on Pt black, indicating that the $\mathrm{C}-\mathrm{C}$ bonds of ethanol are more easily broken on octahedral $\mathrm{Pt}_{59} \mathrm{Cu}_{41}$ nanoalloys than Pt black, resulting in more energy release and better activity. Compared with methanol oxidation, ethanol oxidation produces less carbon dioxide, which means the most $\mathrm{C}-\mathrm{C}$ carbon bonds are not fully broken, forming a lot of carboxylate species which are toxic species for electrocatalyst (Reactions 1,2) [67,68].

$$
\begin{gathered}
\mathrm{CH}_{3} \mathrm{CH}_{2} \mathrm{OH}+\mathrm{OH}^{-}+\mathrm{Pt} \rightarrow \mathrm{Pt}-\mathrm{OCH}_{2} \mathrm{CH}_{3}+\mathrm{H}_{2} \mathrm{O}+\mathrm{e}, \\
\mathrm{Pt}-\mathrm{OCH}_{2} \mathrm{CH}_{3} \rightarrow \mathrm{Pt}-\mathrm{OCH}(\mathrm{OH}) \mathrm{CH}_{3} \\
\rightarrow \mathrm{Pt}-\mathrm{OC}(=\mathrm{O}) \mathrm{CH}_{3} .
\end{gathered}
$$

Compared with ethanol oxidation (Reaction 3), methanol is prone to completely oxidized to $\mathrm{CO}_{2}$ and only forms a small amount of carboxylate (Reaction 4), and thus the durability on octahedral $\mathrm{Pt}_{59} \mathrm{Cu}_{41}$ nanoalloys toward methanol oxidation is much better than that toward ethanol oxidation [67].

$$
\begin{aligned}
& \mathrm{CH}_{3} \mathrm{CH}_{2} \mathrm{OH}+5 \mathrm{OH}^{-} \rightarrow \mathrm{CH}_{3} \mathrm{COO}^{-}+4 \mathrm{H}_{2} \mathrm{O}+4 \mathrm{e}^{-}, \\
& \mathrm{CH}_{3} \mathrm{OH}+8 \mathrm{OH}^{-} \rightarrow \mathrm{CO}_{3}^{2-}+6 \mathrm{H}_{2} \mathrm{O}+6 \mathrm{e}^{-} .
\end{aligned}
$$

\section{CONCLUSIONS}

In summary, a series of composition-tunable PtCu octahedral nanoalloys were synthesized by using sodium halides $(\mathrm{NaBr}$ or/and $\mathrm{NaI})$ as structure-directing agents. The as-prepared $\mathrm{PtCu}$ octahedral nanoalloys display composition-dependent catalytic performances toward methanol and ethanol oxidation. Taking advantages of the ligand effect, synergetic effect and strain effect, specific activity/ mass activity on $\mathrm{Pt}_{59} \mathrm{Cu}_{41}$ octahedron can be $31.9 \mathrm{~mA} \mathrm{~cm}^{-2} / 5.12 \mathrm{~A} \mathrm{mg}^{-1}$ Pt toward methanol oxidation; 
$45.62 \mathrm{~mA} \mathrm{~cm}^{-2} / 7.3 \mathrm{~A} \mathrm{mg}^{-1}$ pt toward ethanol oxidation, in $1.0 \mathrm{~mol} \mathrm{~L}^{-1}$ methanol/ethanol solution, respectively. These values are much higher than that of commercial Pt/ Pd black. The in situ FTIR spectroscopy indicated that the $\mathrm{Pt}_{59} \mathrm{Cu}_{41}$ octahedral nanoalloys show better capacity to activate water and methanol/ethanol, and as a result, less CO-like poisoning intermediates will be adsorbed on the surfaces of $\mathrm{Pt}_{59} \mathrm{Cu}_{41}$ octahedral nanoalloy, compared with commercial Pt black. Moreover, $\mathrm{Pt}_{59} \mathrm{Cu}_{41}$ octahedral nanoalloys are able to break $\mathrm{C}-\mathrm{C}$ bonds of ethanol more easily than commercial Pt black. Our studies not only offer a simple route for the preparation of compositiontunable PtCu octahedral nanoalloys, but also give insights into the structural evidences in terms of activity and durability for both methanol and ethanol electrooxidation in alkaline medium.

\section{Received 10 April 2019; accepted 14 June 2019; published online 11 July 2019}

1 Mao J, Chen W, He D, et al. Design of ultrathin Pt-Mo-Ni nanowire catalysts for ethanol electrooxidation. Sci Adv, 2017, 3: e1603068

2 Huang W, Wang H, Zhou J, et al. Highly active and durable methanol oxidation electrocatalyst based on the synergy of platinumnickel hydroxide-graphene. Nat Commun, 2015, 6: 10035

$3 \mathrm{Bu} \mathrm{L}$, Shao Q, Huang X. Highly porous $\mathrm{Pt}-\mathrm{Pb}$ nanostructures as active and ultrastable catalysts for polyhydric alcohol electrooxidations. Sci China Mater, 2019, 62: 341-350

4 Gamler JTL, Ashberry HM, Skrabalak SE, et al. Random alloyed versus intermetallic nanoparticles: a comparison of electrocatalytic performance. Adv Mater, 2018, 30: 1801563

5 Zhang Y, Zhang J, Chen Z, et al. One-step synthesis of the PdPt bimetallic nanodendrites with controllable composition for methanol oxidation reaction. Sci China Mater, 2018, 61: 697-706

6 Fan J, Qi K, Zhang L, et al. Engineering Pt/Pd interfacial electronic structures for highly efficient hydrogen evolution and alcohol oxidation. ACS Appl Mater Interfaces, 2017, 9: 18008-18014

7 Liu H, Liu K, Zhong P, et al. Ultrathin Pt-Ag alloy nanotubes with regular nanopores for enhanced electrocatalytic activity. Chem Mater, 2018, 30: 7744-7751

8 Gao D, Li S, Song G, et al. One-pot synthesis of $\mathrm{Pt}-\mathrm{Cu}$ bimetallic nanocrystals with different structures and their enhanced electrocatalytic properties. Nano Res, 2018, 11: 2612-2624

9 Xia T, Liu J, Wang S, et al. Nanomagnetic CoPt truncated octahedrons: facile synthesis, superior electrocatalytic activity and stability for methanol oxidation. Sci China Mater, 2017, 60: 57-67

10 Song $\mathrm{P}$, Cui X, Shao Q, et al. Networked Pt-Sn nanowires as efficient catalysts for alcohol electrooxidation. J Mater Chem A, 2017, 5: 24626-24630

11 Fu QQ, Li HH, Ma SY, et al. A mixed-solvent route to unique $\mathrm{PtAuCu}$ ternary nanotubes templated from $\mathrm{Cu}$ nanowires as efficient dual electrocatalysts. Sci China Mater, 2016, 59: 112-121

$12 \mathrm{Du} \mathrm{H}$, Luo S, Wang K, et al. High-quality and deeply excavated $\mathrm{Pt}_{3} \mathrm{Co}$ nanocubes as efficient catalysts for liquid fuel electrooxidation. Chem Mater, 2017, 29: 9613-9617

13 Tao Z, Chen W, Yang J, et al. Ultrathin yet transferrable Pt- or
PtRu-decorated graphene films as efficient electrocatalyst for methanol oxidation reaction. Sci China Mater, 2019, 62: 273-282

14 Huang L, Han Y, Zhang X, et al. One-step synthesis of ultrathin $\mathrm{Pt}_{x} \mathrm{~Pb}$ nerve-like nanowires as robust catalysts for enhanced methanol electrooxidation. Nanoscale, 2017, 9: 201-207

15 Sun $\mathrm{Y}$, Liang $\mathrm{Y}$, Luo $\mathrm{M}$, et al. Defects and interfaces on $\mathrm{PtPb}$ nanoplates boost fuel cell electrocatalysis. Small, 2018, 14: 1702259

16 Chen Q, Yang Y, Cao Z, et al. Excavated cubic platinum-tin alloy nanocrystals constructed from ultrathin nanosheets with enhanced electrocatalytic activity. Angew Chem Int Ed, 2016, 55: 9021-9025

17 Zhao Y, Liu J, Liu C, et al. Amorphous CuPt alloy nanotubes induced by $\mathrm{Na}_{2} \mathrm{~S}_{2} \mathrm{O}_{3}$ as efficient catalysts for the methanol oxidation reaction. ACS Catal, 2016, 6: 4127-4134

18 Hong W, Wang J, Wang E. Facile synthesis of $\mathrm{PtCu}$ nanowires with enhanced electrocatalytic activity. Nano Res, 2015, 8: 23082316

19 Chen Q, Cao Z, Du G, et al. Excavated octahedral Pt-Co alloy nanocrystals built with ultrathin nanosheets as superior multifunctional electrocatalysts for energy conversion applications. Nano Energy, 2017, 39: 582-589

20 Din MAU, Saleem F, Ni B, et al. Porous tetrametallic PtCuBiMn nanosheets with a high catalytic activity and methanol tolerance limit for oxygen reduction reactions. Adv Mater, 2017, 29: 1604994

21 Zhang Z, Luo Z, Chen B, et al. One-pot synthesis of highly anisotropic five-fold-twinned $\mathrm{PtCu}$ nanoframes used as a bifunctional electrocatalyst for oxygen reduction and methanol oxidation. Adv Mater, 2016, 28: 8712-8717

22 Yan SY, Huang YR, Yang CY, et al. Enhanced activity of ethanol oxidation reaction on PtM ( $\mathrm{M}=\mathrm{Au}, \mathrm{Ag}$ and $\mathrm{Sn})$ : The importance of oxophilicity and surface oxygen containing species. Electrochim Acta, 2018, 259: 733-741

23 Kuttiyiel KA, Choi YM, Sasaki K, et al. Tuning electrocatalytic activity of Pt monolayer shell by bimetallic Ir-M ( $\mathrm{M}=\mathrm{Fe}, \mathrm{Co}, \mathrm{Ni}$ or $\mathrm{Cu})$ cores for the oxygen reduction reaction. Nano Energy, 2016, 29: 261-267

24 Eid K, Ahmad YH, Yu H, et al. Rational one-step synthesis of porous PtPdRu nanodendrites for ethanol oxidation reaction with a superior tolerance for CO-poisoning. Nanoscale, 2017, 9: 18881-18889

25 Qi Z, Xiao C, Liu C, et al. Sub-4 nm PtZn intermetallic nanoparticles for enhanced mass and specific activities in catalytic electrooxidation reaction. J Am Chem Soc, 2017, 139: 4762-4768

26 Xiang S, Wang L, Huang CC, et al. Concave cubic PtLa alloy nanocrystals with high-index facets: Controllable synthesis in deep eutectic solvents and their superior electrocatalytic properties for ethanol oxidation. J Power Sources, 2018, 399: 422-428

27 Zhang E, Ma F, Liu J, et al. Porous platinum-silver bimetallic alloys: surface composition and strain tunability toward enhanced electrocatalysis. Nanoscale, 2018, 10: 21703-21711

28 Xue S, Deng W, Yang F, et al. Hexapod PtRuCu nanocrystalline alloy for highly efficient and stable methanol oxidation. ACS Catal, 2018, 8: 7578-7584

29 Liu T, Wang K, Yuan Q, et al. Monodispersed sub-5.0 nm PtCu nanoalloys as enhanced bifunctional electrocatalysts for oxygen reduction reaction and ethanol oxidation reaction. Nanoscale, 2017, 9: 2963-2968

30 Sun X, Jiang K, Zhang N, et al. Crystalline control of $\{111\}$ bounded $\mathrm{Pt}_{3} \mathrm{Cu}$ nanocrystals: multiply-twinned $\mathrm{Pt}_{3} \mathrm{Cu}$ icosahedra with enhanced electrocatalytic properties. ACS Nano, 2015, 9: 7634-7640

31 Yin AX, Min XQ, Zhang YW, et al. Shape-selective synthesis and 
facet-dependent enhanced electrocatalytic activity and durability of monodisperse sub-10 nm Pt-Pd tetrahedrons and cubes. J Am Chem Soc, 2011, 133: 3816-3819

32 Hsu SW, Tao AR. Halide-directed synthesis of square prismatic Ag nanocrystals by the polyol method. Chem Mater, 2018, 30: 46174623

33 Qin Y, Luo M, Sun Y, et al. Intermetallic hcp-PtBi/fcc-Pt core/shell nanoplates enable efficient bifunctional oxygen reduction and methanol oxidation electrocatalysis. ACS Catal, 2018, 8: 5581-5590

34 Jiang B, Li C, Dag Ö, et al. Mesoporous metallic rhodium nanoparticles. Nat Commun, 2017, 8: 15581

35 Luo S, Shen PK. Concave platinum-copper octopod nanoframes bounded with multiple high-index facets for efficient electrooxidation catalysis. ACS Nano, 2017, 11: 11946-11953

36 Xiong Y, Ma Y, Li J, et al. Strain-induced Stranski-Krastanov growth of Pd@Pt core-shell hexapods and octapods as electrocatalysts for methanol oxidation. Nanoscale, 2017, 9: 11077-11084

37 Sahraie NR, Kramm UI, Steinberg J, et al. Quantifying the density and utilization of active sites in non-precious metal oxygen electroreduction catalysts. Nat Commun, 2015, 6: 8618

38 Liu C, Ma Z, Cui M, et al. Favorable core/shell interface within $\mathrm{Co}_{2} \mathrm{P} / \mathrm{Pt}$ nanorods for oxygen reduction electrocatalysis. Nano Lett, 2018, 18: 7870-7875

39 Dragoi B, Mazilu I, Chirieac A, et al. Highly dispersed copper (oxide) nanoparticles prepared on SBA-15 partially occluded with the P123 surfactant: toward the design of active hydrogenation catalysts. Catal Sci Technol, 2017, 7: 5376-5385

40 Huang L, Zhang X, Wang Q, et al. Shape-control of Pt-Ru nanocrystals: tuning surface structure for enhanced electrocatalytic methanol oxidation. J Am Chem Soc, 2018, 140: 1142-1147

41 Kuang Y, Cai Z, Zhang Y, et al. Ultrathin dendritic $\mathrm{Pt}_{3} \mathrm{Cu}$ triangular pyramid caps with enhanced electrocatalytic activity. ACS Appl Mater Interfaces, 2014, 6: 17748-17752

42 Nosheen F, Zhang Z, Xiang G, et al. Three-dimensional hierarchical Pt-Cu superstructures. Nano Res, 2015, 8: 832-838

43 Eid $\mathrm{K}$, Wang $\mathrm{H}$, He $\mathrm{P}$, et al. One-step synthesis of porous bimetallic PtCu nanocrystals with high electrocatalytic activity for methanol oxidation reaction. Nanoscale, 2015, 7: 16860-16866

44 Li Z, Xu S, Xie Y, et al. Promotional effects of trace Bi on its highly catalytic activity for methanol oxidation of hollow Pt/graphene catalyst. Electrochim Acta, 2018, 264: 53-60

45 Li D, Cai K, Wu L, et al. Ammonia mediated one-step synthesis of three-dimensional porous $\mathrm{Pt}_{x} \mathrm{Cu}_{100-x}$ nanochain networks with enhanced electrocatalytic activity toward polyhydric alcohol oxidation. ACS Sustain Chem Eng, 2017, 5: 11086-11095

46 Bai J, Xiao X, Xue YY, et al. Bimetallic platinum-rhodium alloy nanodendrites as highly active electrocatalyst for the ethanol oxidation reaction. ACS Appl Mater Interfaces, 2018, 10: 1975519763

47 Xu D, Bliznakov S, Liu Z, et al. Composition-dependent electrocatalytic activity of $\mathrm{Pt}-\mathrm{Cu}$ nanocube catalysts for formic acid oxidation. Angew Chem Int Ed, 2010, 49: 1282-1285

48 Ding J, Bu L, Guo S, et al. Morphology and phase controlled construction of Pt-Ni nanostructures for efficient electrocatalysis. Nano Lett, 2016, 16: 2762-2767

49 Strasser P. Catalysts by Platonic design. Science, 2015, 349: 379380

50 Li C, Liu T, He T, et al. Composition-driven shape evolution to $\mathrm{Cu}$-rich $\mathrm{PtCu}$ octahedral alloy nanocrystals as superior bifunctional catalysts for methanol oxidation and oxygen reduction re- action. Nanoscale, 2018, 10: 4670-4674

51 Beermann V, Gocyla M, Willinger E, et al. Rh-doped Pt-Ni octahedral nanoparticles: understanding the correlation between elemental distribution, oxygen reduction reaction, and shape stability. Nano Lett, 2016, 16: 1719-1725

52 Xiao W, Liutheviciene Cordeiro MA, Gong M, et al. Optimizing the ORR activity of Pd based nanocatalysts by tuning their strain and particle size. J Mater Chem A, 2017, 5: 9867-9872

53 Fu S, Zhu C, Shi Q, et al. Highly branched PtCu bimetallic alloy nanodendrites with superior electrocatalytic activities for oxygen reduction reactions. Nanoscale, 2016, 8: 5076-5081

54 Xiong Y, Shan $\mathrm{H}$, Zhou Z, et al. Tuning surface structure and strain in Pd-Pt core-shell nanocrystals for enhanced electrocatalytic oxygen reduction. Small, 2017, 13: 1603423

55 You H, Yang S, Ding B, et al. Synthesis of colloidal metal and metal alloy nanoparticles for electrochemical energy applications. Chem Soc Rev, 2013, 42: 2880-2904

56 Zhao R, Liu Y, Liu C, et al. Pd@Pt core-shell tetrapods as highly active and stable electrocatalysts for the oxygen reduction reaction. J Mater Chem A, 2014, 2: 20855-20860

57 Li ZY, Zhou J, Tang LS, et al. Hydroxyl-rich ceria hydrate nanoparticles enhancing the alcohol electrooxidation performance of $\mathrm{Pt}$ catalysts. J Mater Chem A, 2018, 6: 2318-2326

58 Huang DB, Yuan Q, He PL, et al. A facile and general strategy for the synthesis of porous flowerlike Pt-based nanocrystals as effective electrocatalysts for alcohol oxidation. Nanoscale, 2016, 8: 1470514710

59 Jiang K, Bu L, Wang P, et al. Trimetallic PtSnRh wavy nanowires as efficient nanoelectrocatalysts for alcohol electrooxidation. ACS Appl Mater Interfaces, 2015, 7: 15061-15067

60 Yuan X, Jiang X, Cao M, et al. Intermetallic PtBi core/ultrathin Pt shell nanoplates for efficient and stable methanol and ethanol electro-oxidization. Nano Res, 2019, 12: 429-436

61 Liu H, Li J, Wang L, et al. Trimetallic PtRhNi alloy nanoassemblies as highly active electrocatalyst for ethanol electrooxidation. Nano Res, 2017, 10: 3324-3332

62 Han SH, Liu HM, Chen P, et al. Porous trimetallic PtRhCu cubic nanoboxes for ethanol electrooxidation. Adv Energy Mater, 2018, 8: 1801326

63 Wang Y, Wang W, Xue F, et al. One-pot synthesis of $\mathrm{Pd@Pt} \mathrm{Ni}_{3}$ core-shell nanobranches with ultrathin $\mathrm{Pt}_{3} \mathrm{Ni}\{111\}$ skins for efficient ethanol electrooxidation. Chem Commun, 2018, 54: 5185-5188

64 Beyhan S, Uosaki K, Feliu JM, et al. Electrochemical and in situ FTIR studies of ethanol adsorption and oxidation on gold single crystal electrodes in alkaline media. J Electroanal Chem, 2013, 707: 89-94

65 Zhang BW, Jiang YX, Ren J, et al. PtBi intermetallic and PtBi intermetallic with the Bi-rich surface supported on porous graphitic carbon towards $\mathrm{HCOOH}$ electro-oxidation. Electrochim Acta, 2015, 162: 254-262

66 Li JT, Zhou ZY, Broadwell I, et al. In-situ infrared spectroscopic studies of electrochemical energy conversion and storage. Acc Chem Res, 2012, 45: 485-494

67 Pech-Rodríguez WJ, González-Quijano D, Vargas-Gutiérrez G, et al. Electrochemical and in situ FTIR study of the ethanol oxidation reaction on $\mathrm{PtMo} / \mathrm{C}$ nanomaterials in alkaline media. Appl Catal B-Environ, 2017, 203: 654-662

68 Christensen PA, Jones SWM, Hamnett A. In situ FTIR studies of ethanol oxidation at polycrystalline Pt in alkaline solution. J Phys Chem C, 2012, 116: 24681-24689 


\begin{abstract}
Acknowledgements This work was supported by the National Natural Science Foundation of China (21571038 and 21361005), the Open Fund of the Key Lab of Organic Optoelectronics \& Molecular Engineering (Tsinghua University), the Foundation for Excellent Young Scientific and Technological Talents of Guizhou Province (2019-5666) and the Special Fund for Natural Science of Guizhou University (201801). We also appreciate Prof. Xun Wang (Tsinghua University) for HRTEM experiments.
\end{abstract}

Author contributions Zhao F synthesized the $\mathrm{PtCu}$ nanocrystals and performed the electrochemical test. Zhao F, Luo B, Li C, Yang F and Yang X carried out the structure characterization. Zhou $Z$ tested the in situ FTIR. Yuan Q and Zhao F conceived this work and wrote the manuscript. All authors discussed the experiment results.

Conflict of interest There are no conflicts of interest to declare.

Supplementary information Instruments, CV characterizations and supporting data are available in the online version of this paper.

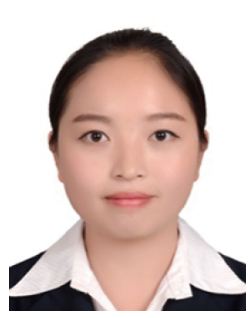

Fengling Zhao obtained her BSc degree in chemistry from Guizhou University (2013). Then she joined Prof. Yuan's group as a graduate student at the Department of Chemistry, College of Chemistry and Chemical Engineering, Guizhou University. Her current research interests focus on noble metals based nanomaterials for controlled synthesis and electrochemical applications.

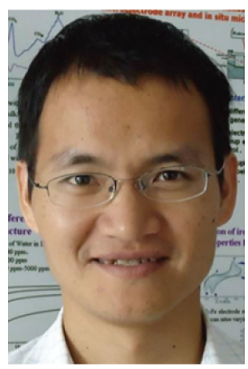

Zhiyou Zhou received his $\mathrm{PhD}$ degree in 2004 from Xiamen University. He is a professor at the Department of Chemistry of Xiamen University and his research interests include electrochemical in situ FTIRs, electrocatalysis, fuel cells and nanomaterials.

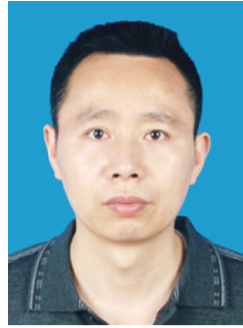

Qiang Yuan is a professor at the Department of Chemistry, College of Chemistry and Chemical Engineering, Guizhou University. He received his $\mathrm{PhD}$ degree in 2006 from Xiamen University. From 2008 to 2012, he was a postdoctoral research fellow in Tsinghua University ( Prof. Xun Wang's group), National University of Singapore (Prof. Hua Chun Zeng's group) and King Abdullah University of Science \& Technology (Prof. Muhammad Mustafa Hussain's group). He was a visiting scholar of "Light of the West" in Prof. Xun Wang's group in Tsinghua University from September 2017 to July 2018. His current research interests include synthetic methodology, selfassembly and electrochemical properties of metal nanocrystals.

\section{表面组成和应变可调的PtCu八面体纳米合金促进 甲醇和乙醇电催化性能}

赵风玲 ${ }^{1}$, 袁强 ${ }^{1,2^{*}}$, 罗斌 ${ }^{1}$, 李朝忠 ${ }^{1}$, 杨芳 ${ }^{1}$, 杨晓劸 ${ }^{1}$, 周志有 ${ }^{3}$

摘要 本文介绍了一种以卤素离子 $\left(\mathrm{Br}^{-}\right.$或 $/$和 $\left.\mathrm{I}^{-}\right)$为成分调变剂制备 组成和应变可调的 $\mathrm{PtCu}$ 八面体纳米合金的简便方法. 由于纳米合 金化所产生的配位效应、协同效应和应变效应, $\mathrm{PtCu}$ 八面体纳米 合金在碱性介质中对甲醇和乙醇电氧化表现出优于商业 $\mathrm{Pt}$ 黑的催 化性能. 在这些 $\mathrm{PtCu}$ 八面体纳米合金中, 优化的 $\mathrm{Pt}_{59} \mathrm{Cu}_{41}$ 八面体纳 米合金具有较高的催化活性和耐久性. 对于甲醇氧化, $\mathrm{Pt}_{59} \mathrm{Cu}_{41}$ 八 面体的比活性/质量活性为 $20.25 \mathrm{~mA} \mathrm{~cm}{ }^{-2} / 3.24 \mathrm{~A} \mathrm{mg}^{-1} \mathrm{Pt}$, 分别是商 业铂黑的6.64/5.3倍. 对于乙醇氧化, $\mathrm{Pt}_{59} \mathrm{Cu}_{41}$ 八面体的比活性/质量 活性为 $34.84 \mathrm{~mA} \mathrm{~cm}^{-2} / 5.58 \mathrm{~A} \mathrm{mg}^{-1} \mathrm{Pt}$, 分别是商业铂黑的 9.16/7.34 倍. 利用原位傅立叶变换红外光谱技术, 对甲醇/乙醇氧化反应中 的中间物种和产物进行了检测, 并探讨了 $\mathrm{Pt}_{59} \mathrm{Cu}_{41}$ 八面体催化活性 和耐久性较好的原因, 同时解释了在碱性介质中甲醇氧化耐久性 优于乙醇的原因. 本文对探索制备高性能的碱性甲醇/乙醇燃料电 池纳米电催化剂具有一定的科学意义. 